\title{
Significance of historical and cultural architectural heritage of Kaliningrad region
}

\author{
Yuri Yurievich Filippov* \\ Immanuel Kant Baltic Federal University, Kaliningrad, Russian Federation
}

\begin{abstract}
This article is dedicated to the current state and actual use of the unique historical and cultural architectural heritage of Kaliningrad region. A review of scientific works dealing with issues related to the consideration of the existence, ownership, preservation, operation, and perception of architectural objects in the city and region is given. The study gives a species characteristic of historical and cultural heritage objects in Kaliningrad region, makes their classification with specific examples, assesses their current state and current use. The article focuses on significance and determination of the value of preserved historical and cultural resources. The multifaceted value of the region's unique historical and cultural heritage is examined and defined.
\end{abstract}

\section{Introduction}

The historical and cultural heritage of Kaliningrad Region today is under the close attention of almost all representatives of society in the region - local residents and visitors, public organizations and activists, government agencies, entrepreneurs and scientists. In addition, this resource is certainly an anchoring element of the tourism industry. An up-to-date understanding of the problematic aspects of this sphere is currently the most important issue, and the underestimation of the importance of preservation and effective use of historical resources is a global challenge that is overdue and needs to be addressed. In this regard, the purpose of this study is to identify and justify the significance of the cultural heritage of Kaliningrad region.

\section{Materials and methods}

The following methods were chosen for this study: observation, comparison, analysis and generalization, text analysis. The observation was used when visiting and examining the external condition of the architectural objects of the city of Kaliningrad, and also allowed to establish the fact of their modern use. The comparison made it possible to make an assessment of the degree of architectural monuments preservation and it was used in compilation of the evaluation table. With the help of the analysis and generalization, the classification of the existing historical and cultural objects of Kaliningrad was made and the specific value characteristics were determined.

${ }^{*}$ Corresponding author: iufilippov@kantiana.ru 
Issues of global and local cultural heritage are studied at all levels, the topic of conservation and effective management is considered in the works of Algafri M.A. [3], Almahameed M. [11], Facchinetti S. [12], etc.

The problems of the region heritage have also been studied by scientists for a long time and constantly. The most difficult problem in modern studies of this subject is the question of understanding the essence of possession of historical heritage and understanding its significance not just as an existing property, but as part of the Russian, European and world culture. In this context, two directions are defined - the present perception of the problem by society and scientifically based interpretations of domestic scientists (Kostyashov Yu.V. [6], Belintseva I.V. [4], Zotova M.V. and Sebentsov A.B. [5], Mosienko E.P. [8], Mitrofanova A.V. and Filippov Yu.Yu. [7], Pazylova G.A. and Anokhin A. Yu. [9], etc.). In general, it should be noted that virtually all authors who study the issues of historical and cultural heritage agree on one thing - this resource is very important and should be preserved.

\section{Results and discussion}

It should be emphasized once again that Kaliningrad region is a unique territory of the Russian Federation as possessor of a special historical heritage formed by another nation. At the same time, there is currently no specific understanding/awareness of the importance of these resources for the region in particular and for the country as a whole. The lack of a clear, thoughtful and long-term policy on the historical architectural heritage, both in the narrow sense (monuments subject to state protection) and in the broadest sense - as an existing historic material landscape - is the main problem of its current state and prospective use.

For a complete definition of the existing situation, it is initially necessary to give a brief characteristic of what is meant by the main object of research - cultural heritage.

First, according to the Federal Law "On Objects of Cultural Heritage (Historical and Cultural Monuments) of the peoples of the Russian Federation", (Federal Law No. 73 "On Objects of Cultural Heritage (Historical and Cultural Monuments) of the Peoples of the Russian Federation" dated June 25, 2002.) "objects of cultural heritage (historical and cultural monuments) of the peoples of the Russian Federation ... include objects of immovable property ... and other objects with historically related territories ... objects of science and technology and other objects of material culture that have arisen as a result of historical events, are valuable from the point of view of history ... architecture, urban planning, art, science and technology, aesthetics, ethnology ... social culture and are evidence of epochs and civilizations, authentic sources of information about the origin and development of culture" (Ibid.). For clarification it should be noted that under the same law one of the types of cultural heritage objects is defined as "separate structures, buildings and constructions with historically established areas (including religious monuments, which in accordance with Federal Law dated November 30, 2010 N 327-FZ "On the Transfer to Religious Organizations of Religious Property Located in State or Municipal Ownership") ... objects of science and technology, including military...".

Secondly, the object of study should also include historic urban architecture, not identified as objects of cultural heritage of any level, but which has the potential to acquire the appropriate status. Such buildings are part of the old buildings of the city, represent a particular stage of its development, have signs of such monuments, among which can be called such as:

- $\quad$ signs of real estate (real estate buildings, structures, buildings, as well as their historical territory);

- architectural features (architectural style, rare exterior and/or interior, unique elements or details of the building/decoration, special building material, original design, etc.); 
- $\quad$ cultural attributes (the structure may be connected with certain historical or cultural events and/or personalities);

- age features (a certain period of time should pass since the object creation, the duration of which can be established in the examination process, the same period applies to the historical events connected with these structures).

Further, on the basis of the definitions of the Federal Law, the object under study should be classified. In Kaliningrad and on the territory of the region, four main types of monuments have been preserved (List of monuments of historical and cultural heritage // Administration of urban district "City of Kaliningrad": official site: official site. URL: https://www.klgd.ru/activity/social/culture/memory/spisok.php (reference date May 27, 2021).) from the historical period of East Prussia, depending on their original functional purpose (see Table 1):

- civilians,

- military,

- industrial,

- cultic.

Table 1. Types of architectural monuments of the historical and cultural heritage of Kaliningrad region (compiled by the author).

\begin{tabular}{|c|c|c|c|c|}
\hline No. & Type name & $\begin{array}{l}\text { Type of architectural object } \\
\text { (examples) }\end{array}$ & $\begin{array}{c}\text { The degree of } \\
\text { preservation } \\
\text { and use in } \\
\text { general }(+)\end{array}$ & $\begin{array}{l}\text { The degree of } \\
\text { preservation } \\
\text { and use in } \\
\text { general }(-)\end{array}$ \\
\hline \multirow[t]{5}{*}{1.} & \multirow[t]{5}{*}{ Civil architecture } & - administrative buildings & + & \\
\hline & & - residential development & + & \\
\hline & & - aristocratic estates & & - \\
\hline & & $\begin{array}{l}\text { - educational infrastructure } \\
\text { buildings }\end{array}$ & + & - \\
\hline & & $\begin{array}{l}\text { - health infrastructure buildings, } \\
\text { etc. }\end{array}$ & + & \\
\hline \multirow[t]{4}{*}{2.} & \multirow{4}{*}{$\begin{array}{l}\text { Military } \\
\text { architecture }\end{array}$} & - objects of defensive fortification & + & - \\
\hline & & - military barracks & & - \\
\hline & & $\begin{array}{l}\text { - warehouses for supply needs of } \\
\text { formation of armed forces }\end{array}$ & & - \\
\hline & & $\begin{array}{l}\text { - defensive structures and civil } \\
\text { defense facilities, etc. }\end{array}$ & & - \\
\hline \multirow[t]{5}{*}{3.} & \multirow{5}{*}{$\begin{array}{l}\text { Industrial } \\
\text { architecture }\end{array}$} & - production complexes & & - \\
\hline & & - factories & & - \\
\hline & & - warehouses and storage facilities & & - \\
\hline & & - transport infrastructure & + & \\
\hline & & - water supply system, etc. & + & - \\
\hline \multirow[t]{2}{*}{4.} & \multirow{2}{*}{$\begin{array}{l}\text { Cultic } \\
\text { architecture }\end{array}$} & - Protestant churches & + & - \\
\hline & & - knight's castles & & - \\
\hline
\end{tabular}

Based on the assessment presented in the table, it can be noted that the degree of preservation and use of cultural heritage monuments is generally negative. All four types are in different forms of ownership, degree of preservation and types of operation. Let us give a brief description of each type with corresponding examples of actual use directly in Kaliningrad.

The most diverse, numerous and most used type can be called civil architecture, in which the following may serve as a model: 
- the majority of administrative buildings located in the center of Kaliningrad are occupied by the city and regional authorities (building of East Prussia Financial Administration - Government of Kaliningrad region, building of Königsberg Trading Yard - City Hall of Kaliningrad, building of Police Presidium - Administration of Federal Security Service in Kaliningrad region, building of Supreme Directorate of Posts - headquarters of Twice Red Banner Baltic Fleet, etc.);

- $\quad$ residential development is mainly used for its direct purpose - for multi-family or individual housing, as well as partially occupied by commercial enterprises (e.g., former Königsberg districts of Amalienau - Kutuzova Street and adjacent streets and Maraunenhof - Telman Street and adjacent streets, etc.);

- the majority of the buildings of the educational institutions of Königsberg now perform the same functions (for example, Real Gymnasium on the Burg-Gymnasium No. 1, Rosenau Folk School - Municipal Educational Institution Secondary General School No. 5, building of Königsberg University on Parade Square - one of the academic buildings of Immanuel Kant Baltic Federal University, Königsberg University Sports Palace Palaestra Albertina - Twice Red Banner Baltic Fleet Sports Club, etc.);

- the historical buildings of the healthcare infrastructure are also partly used for their intended purpose as hospitals and polyclinics (the complex of buildings of the City Hospital of mercy - Regional Clinical Hospital of Kaliningrad region, university Surgical Clinic City Hospital No. 4, Königsberg Nursing Home - City Clinical Hospital of Emergency Medicine, etc.).

Military architecture - a special unique resource that has survived in Kaliningrad, primarily in the form of fortifications of the second and third bypass defensive ring of Königsberg. Such monuments are very rare in the world architecture and the more their value not only for the national culture, but also for European and world culture. The preserved city gates of Königsberg of the Second rampart defensive bypass seem to be special objects. Most of them are museumified or work as cultural objects (6 out of 8 ), and, accordingly, are included in the tourist infrastructure of the city, are included in the conditional list of objects of primary tourist display when visiting Kaliningrad. Among them: Friedland Gate Museum of the history of Königsberg, Brandenburg Gate - Museum of marzipan, Friedrichsburg and Royal Gates-branches of the Museum of the World Ocean, Railway Gate -Planetarium n.a. F.V. Bessel, Zackheim Gate - a public art platform space; the exceptions are the Rosgarten Gate, which houses a restaurant, and the Ausfahl Gate, which over time turned out to be below the level of the road floor and are only accessible for external inspection. However, this use of former military facilities can be called the exception rather than a trend, as will be described below.

As for the fortifications of the third defensive ring of Koenigsberg, only two of them are tourist sites - Fort No. 5 - History Museum of World War II and Fort No. 11 - Museum of Fortification and Military Architecture.

The most difficult type of monuments to preserve is the industrial architecture of the former Königsberg. In general, until the early 2000s, it was used for its intended purpose as industrial facilities with operating production. However, due to processes of deindustrialization, economic problems and loss of relevance, the enterprises subsequently lost their viability and most facilities ceased to function. At present, their fate is as uncertain as possible for a variety of reasons - the complexity of adaptation, the scale of the sites, the contamination of the areas, the degree of preservation, property rights, etc.

The last type of architectural monuments, preserved from the German period - places of worship. At the moment, all of them are owned by the Russian Orthodox Church (Law of Kaliningrad region dated October 28, 2010 No. 502 "On the gratuitous transfer to the ownership of the centralized religious organization "Kaliningrad Diocese of the Russian Orthodox Church (Moscow Patriarchate)" of objects of religious purpose that are in the state 
ownership of Kaliningrad region".) and, with rare exceptions, are used by cultural institutions of Kaliningrad and the region (the Konigsberg Cathedral- GAU of the Kaliningrad region Cathedral - museum, concert hall; the Church of the Memory of Queen Louise - Kaliningrad Regional Puppet Theater; the Church of the Holy Family - Kaliningrad Regional Philharmonic n.a. E.F. Svetlanov et al.). Since this complex of monuments has a single owner, it is managed centrally, which means that it is virtually impossible to influence this management primarily by the public. For this reason, the religious buildings of Kaliningrad and Kaliningrad region cannot be the object of this study.

In general, the uniqueness of the monuments of local architecture creates the concept of variety value (see Figure 1), which in turn forms the context of their significance.

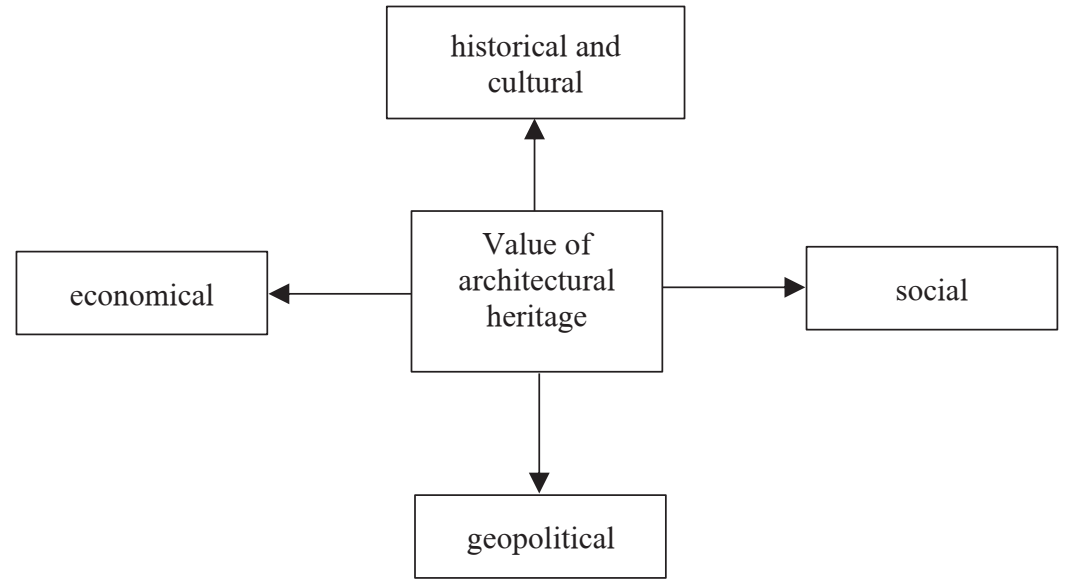

Fig. 1. Types of values shaped by architectural heritage (compiled by the author).

Historical and cultural value is presented as the result of accumulated experience of human civilization development over a certain period of time, while being part of the global heritage. The level of this type of value increases due to the fact that the state and culture that previously existed in this territory at the moment ceased to exist more than seventy-five years ago. And the task of the modern population is not only formation of their own culture, but also the preservation and translation of the former one. In this regard, historical and cultural value is the most complex and, at the same time, the most fragile and vulnerable in terms of its awareness, acceptance and application.

The social value of the region architectural heritage is understood as a way to enlighten, train mentally and educate present and future generations through the study and further transmission of the accumulated experience. This experience can be used as a means of forming new skills in each successive generation, can create new forms of interaction and further development of society. Social value contributes to the generation of public identity and a unique cultural code, making the country's multinational diversity even more vibrant.

The geopolitical value of the preserved heritage is first and foremost a fact of historical events of a crucial character that dramatically affected the course of the regional history. And in this case, it does not matter what the origin of this heritage is. A more important role is played by whose hands it is now in and what is the attitude of today's owners toward it in terms of ownership and disposition. The level of this value increases with the transition to an understanding that this territory and everything on it as tangible and intangible resources is no longer simply a trophy inherited from an alien civilization, but a full-fledged property and resource that can be used effectively in one's own interests, saving and benefiting in each of the value areas. 


\section{Conclusion}

Almost any historical architecture is of great interest and is a major factor in the attractiveness of any city, and the more authentic architectural objects, the greater this attractiveness, and therefore contributes to the visit duration and/or repetition. This resource, due to its special value, is able to form:

firstly, the destination attractiveness, attracting both consumers and investments, creating a favorable situation for the development of the territory's economy;

secondly, a special cultural code, creating an original culture, contributing to the expansion of world diversity;

thirdly, the original image of the region, making the area with prospects for development

Thus, in this context, the most important circumstance is the degree of preservation and intended use of such historical sites, as their overall condition and the possibility of access to them (including tourism) increases their value not only as part of the urban space, but also as a factor in the sustainable development of the city as a whole. Of course, the question is not about total restoration or museumification of historical monuments. The process of heritage preservation and maintenance is much more multifaceted and complex, requiring systematic strategic planning and implementation.

\section{References}

1. Law of Kaliningrad region dated October 28, 2010 No. 502 "On the gratuitous transfer to the ownership of the centralized religious organization "Kaliningrad Diocese of the Russian Orthodox Church (Moscow Patriarchate)" of objects of religious purpose that are in the state ownership of Kaliningrad region".

2. Federal Law No. 73 "On Objects of Cultural Heritage (Historical and Cultural Monuments) of the Peoples of the Russian Federation" dated June 25, 2002.

3. M. A. Algafri, Actual issues of economics and management: materials of the VII International Scientific Conference, 3 (Saint-Petersburg: Svoie publishing house, 2019)

4. I. V. Belintseva, Historical expertise. Journal, 3, 123 (2016)

5. M. V. Zotova, A. B. Sebentsov, In the focus of heritage. Collection of articles dedicated to the 80th anniversary of Yu. A. Vedenin and the 25th anniversary of the creation of the Russian Research Institute of Cultural and Natural Heritage named after D.S. Likhachev. Moscow, 478 (Publishing House: Federal State Budgetary Institution of Science Institute of Geography of the Russian Academy of Sciences (Moscow), 2017)

6. Yu. V. Kostyashov, Modernization of culture: from a person of tradition to a creative subject. Materials of the V International Scientific and Practical Conference, 237 (Publishing House: Samara State Institute of Culture (Samara), 2017)

7. A. V. Mitrofanova, Yu. Yu. Filippov, Modern problems of service and tourism, 11(2), 61 (2017)

8. E. P. Mosienko, Questions of the universal architecture history. Founders: Central Research and Design Institute, 1, 210 (Moscow, 2020)

9. G. A. Pazylova, A. Yu. Anokhin, Tourist and recreational potential and features of tourism and service development: Materials of the international scientific and practical conference of Students and postgraduates, 64 (Kaliningrad: Immanuel Kant Baltic Federal University, 2018)

10. List of monuments of historical and cultural heritage. Administration of urban district "City of Kaliningrad": official site: official site. https://www.klgd.ru. 
11. M. Almahameed, Heritage Site Management and Re- inhabiting in the Old City (Case Study: the Ancient City of Bosra), 142 (Master Dissertation has not printed, Damascus University, 2009)

12. S. Facchinetti, Cultural Heritage Management in Myanmar A Gateway to Sustainable Development, 12 (2014) 